\title{
Are we overrating the extra-skeletal benefits of oral vitamin D supplementation?
}

\author{
Giuseppe Lippi ${ }^{1}$, Giovanni Targher ${ }^{2}$ \\ ${ }^{1}$ Section of Clinical Biochemistry, ${ }^{2}$ Section of Endocrinology, Diabetes and Metabolism, University of Verona, Verona, Italy \\ Correspondence to: Prof. Giuseppe Lippi, MD. Section of Clinical Biochemistry, University Hospital of Verona, Piazzale L.A. Scuro 1, 37134 Verona, \\ Italy. Email: giuseppe.lippi@univr.it.
}

Submitted Aug 09, 2019. Accepted for publication Aug 15, 2019.

doi: $10.21037 /$ atm.2019.08.93

View this article at: http://dx.doi.org/10.21037/atm.2019.08.93

Vitamin D (Vit D) is a fat-soluble hormone poorly present in food, which is endogenously produced mainly through the biological conversion of its precursors into the biologically active form (1,25-dihydroxy-cholecalciferol) triggered by ultraviolet radiation exposure from either sunlight or, less frequently, indoor tanning (1). According to the Endocrine Society recommendations, Vit D3 deficiency can be diagnosed when serum 25-hydroxyvitamin D (25OHD) concentration falls below $20 \mathrm{ng} / \mathrm{mL}$ (i.e., $\leq 50 \mathrm{nmol} / \mathrm{L}$ ), whilst Vit D3 insufficiency is conventionally defined as a serum 25OHD concentration between 21-29 ng/mL (i.e., 52.5-75.0 nmol/L) (2). Although severe forms of Vit D3 deficiency are relative rare and mainly manifest as rickets (3), the current worldwide burden of Vit D3 deficiency and insufficiency is alarming, being recently estimated at around $20 \%$ and $50 \%$, respectively (4). This evidence has paved the way to widespread serum Vit D3 testing (5), enhanced oral Vit D3 supplementation (6) and even food fortification in several countries around the world, such as Canada, United States, Finland and India (7). For example, the Endocrine Society currently recommends that at least $600 \mathrm{IU} /$ day of oral Vit D3 are needed in the adulthood to optimize bone health and muscle function (2).

Beside its well-recognized role in calcium homeostasis, Vit D3 may exert a variety of other potential pleiotropic effects $(8,9)$, so that major emphasis is accumulating that oral supplementation might be a promising 'policy' for enhancing global health (10). Nevertheless, a contradictory picture emerges from the analysis of large, randomized, placebo-controlled trials, which have very recently explored the effect of oral Vit D3 supplementation on prevention of common chronic diseases.

Manson et al. carried out a nationwide randomized, placebo-controlled trial, in which 25,871 United States middle-aged individuals free of cardiovascular disease and cancer at the baseline were randomly assigned to receive either 2,000 IU daily of Vit D3 (cholecalciferol) $(\mathrm{n}=12,927)$ or placebo $(n=12,944)(11)$. No significant differences were observed between the supplemented and placebo groups in incidence of major cardiovascular events [hazard ratio (HR), 0.97; $95 \%$ confidence interval (95\% CI), 0.85-1.12] or of any type of cancer (HR, 0.96; 95\% CI, 0.88-1.06) during a median follow-up of 5.3 years. A subgroup analysis, focused on different types of cardiovascular disorders or cancers, showed virtually identical results, whereby the incidence of myocardial infarction (HR, 0.96; 95\% CI, 0.78-1.19), stroke (HR, 0.95; 95\% CI, 0.76-1.20), breast cancer (HR, 1.02; 95\% CI, 0.79-1.31), prostate cancer (HR, 0.88; 95\% CI, 0.72-1.07) and colorectal cancer (HR, 1.09; 95\% CI, 0.73-1.62) were comparable between the two groups.

As regards diabetes, Pittas et al. randomly assigned 2,423 adults at high risk for diabetes to receive 4,000 IU daily of Vit D3 $(n=1,211)$ or placebo $(n=1,212)$, regardless of the baseline serum 25OHD level (12). Although the mean serum 25OHD levels nearly doubled in the Vit D3 supplemented group, the primary outcome of incident type 2 diabetes occurred similarly in the Vit $\mathrm{D}$ and placebo groups (HR, 0.88; 95\% CI, 0.75-1.04; $\mathrm{P}=0.12$ ) during a median follow-up of 2.5 years.

In another recent placebo-controlled trial, Roth 
Table 1 Summary of recent randomized, placebo-controlled trials investigating the effect of oral vitamin D3 supplementation for preventing common chronic diseases

\begin{tabular}{|c|c|c|c|c|c|c|}
\hline $\begin{array}{l}\text { Authors, } \\
\text { year (ref) }\end{array}$ & $\begin{array}{l}\text { Outcome } \\
\text { variable }\end{array}$ & Study design & $\begin{array}{l}\text { Oral Vit D3 } \\
\text { dose (IU/day) }\end{array}$ & $\begin{array}{l}\text { Follow-up } \\
\text { (mean) }\end{array}$ & $\begin{array}{l}\text { Change in serum } \\
25 \mathrm{OHD} \text { levels }(\mathrm{ng} / \mathrm{mL})\end{array}$ & $\begin{array}{l}\text { Main results } \\
\text { (Vit D vs. placebo) }^{1}\end{array}$ \\
\hline $\begin{array}{l}\text { Manson et al., } \\
2019(11)\end{array}$ & $\begin{array}{l}\text { Cardiovascular } \\
\text { disease }\end{array}$ & $\begin{array}{l}\text { Randomization to vitamin } \\
D(n=12,927) \text { or placebo } \\
(n=12,944)\end{array}$ & 2,000 & 5.3 years & From 29.8 to 41.8 & 0.97 (95\% Cl, 0.85-1.12) \\
\hline $\begin{array}{l}\text { Manson et al., } \\
2019(11)\end{array}$ & Cancer & $\begin{array}{l}\text { Randomization to vitamin } \\
D(n=12,927) \text { or placebo } \\
(n=12,944)\end{array}$ & 2,000 & 5.3 years & From 29.8 to 41.8 & $0.96(95 \% \mathrm{Cl}, 0.88-1.06)$ \\
\hline $\begin{array}{l}\text { Pittas et al., } \\
2019(12)\end{array}$ & Diabetes & $\begin{array}{l}\text { Randomization to vitamin } \\
D(n=1,211) \text { or placebo } \\
(n=1,212)\end{array}$ & 4,000 & 2.5 years & From 27.7 to 54.3 & $0.88(95 \% \mathrm{Cl}, 0.75-1.04)$ \\
\hline $\begin{array}{l}\text { Roth et al., } \\
2018 \text { (13) }\end{array}$ & $\begin{array}{l}\text { Anthropometric } \\
\text { parameters in } \\
\text { newborns }\end{array}$ & $\begin{array}{l}\text { Randomization of pregnant } \\
\text { women to vitamin } D \\
(600 \mathrm{IU} / \text { day, } n=260 \text {; } \\
2,400 / \text { day, } n=259 \text {; } \\
4,000 \mathrm{IU} \text { daily, } n=260 \text {; } \\
4,000 \mathrm{IU} / \text { day }+4,000 \mathrm{IU} / \text { day } \\
\text { post-partum, } n=260) \text { or } \\
\text { placebo }(n=260)\end{array}$ & $\begin{array}{l}\text { From } 600 \text { to } \\
4,000\end{array}$ & $\begin{array}{l}1 \text { year } \\
\text { after birth }\end{array}$ & $\begin{array}{l}\text { From } 26.6-27.4 \text { to } \\
69.7-113.6\end{array}$ & $\begin{array}{l}\text { No difference in live } \\
\text { birth, gestational age at } \\
\text { birth or anthropometric } \\
\text { parameters }\end{array}$ \\
\hline $\begin{array}{l}\text { Bischoff- } \\
\text { Ferrari et al., } \\
2012(14)\end{array}$ & $\begin{array}{l}\text { Hip and } \\
\text { non-vertebral } \\
\text { fractures }\end{array}$ & $\begin{array}{l}\text { Randomization to vitamin } \\
D(n=15,527) \text { or placebo } \\
(n=15,495)\end{array}$ & $\begin{array}{l}\text { From } 360 \text { to } \\
2,000\end{array}$ & N/A & $\begin{array}{l}\text { Baseline level } \\
16.4-21.6\end{array}$ & $\begin{array}{l}0.90(95 \% \mathrm{Cl}, 0.50-1.01) \\
\text { for hip fractures and } 0.93 \\
(95 \% \mathrm{Cl}, 0.87-0.99) \text { for } \\
\text { non-vertebral fractures }\end{array}$ \\
\hline
\end{tabular}

${ }^{1}$, data are expressed as hazard ratio and 95\% confidence intervals. N/A, non-available; Vit D, vitamin D; 25OHD, 25-hydroxyvitamin D.

et al. randomly assigned 1,298 pregnant women to receive either oral Vit D3 supplementation from 17 to 24 weeks of gestation until birth (600 IU daily, $\mathrm{n}=260$; 2,400 IU daily, $\mathrm{n}=259$; 4,000 IU daily, n=260; 4,000 IU daily plus 4,000 IU daily post-partum, $\mathrm{n}=260)$ or placebo $(\mathrm{n}=260)(13)$. Among the 1,164 infants who could be evaluated at 1 year of age, live birth, gestational age at birth and multiple anthropometric parameters did not significantly differ among groups of infants whose mothers had received or not Vit D3 supplementation.

Notably, the benefit of oral Vit D3 supplementation for reducing bone fractures has also been questioned by the findings of the meta-analysis of Bischoff-Ferrari et al., who pooled participant-level data involving a total of 31,022 individuals 65 years of age or older from 11 different double-blind, randomized, controlled trials (Vit D3 dosages between 360-2,000 IU daily) (14). A total number of 1,111 incident hip fractures and 3,770 non-vertebral fractures were recorded over the follow-up period. The authors found that risk reduction of hip fractures was nonsignificantly different in participants randomly assigned to receive either oral Vit D3 $(\mathrm{n}=15,527)$ or placebo $(\mathrm{n}=15,495)$ (HR, 0.90; 95\% CI, 0.50-1.01), whilst a modest risk reduction of non-vertebral fractures was noted in the Vit D3 group (HR, 0.93; 95\% CI, 0.87-0.99). Treatmentdose analysis revealed that a beneficial effect on risk of hip and non-vertebral fractures could be obtained only in subjects supplemented with higher doses of oral Vit D3 (>800 IU/day). However, this finding is not really surprising, whereby similar results have been also reported by Aspray et al., who showed that oral Vit D3 supplementation had negligible effects on bone health in the elderly (15).

Collectively, the current evidence from large randomized placebo-controlled trials would lead us to raise reasonable doubts that oral Vit D3 supplementation, at least at conventional daily doses (i.e., between 400-2,000 IU/day), would produce major health benefits, or that it would be able to significantly reduce the incidence and the adverse consequences of the most common chronic diseases (as summarized in Table 1). On the other hand, 
recent evidence has been also published that the upper level of Vit D3 supplementation, recommended by the Endocrine Society, may increase by nearly 4-fold the risk of hypercalciuria, especially when combined with oral calcium supplementation (16), thus possibly increasing the risk of developing kidney stones in predisposed individuals, as recently emphasized by Letavernier and Daudon (17). It is also worthwhile mentioning here that Vit D3 supplementation shall not be considered completely safe, whereby overtreatment may generate some toxic effects (18), whilst widespread oral vit D3 supplementation may also impose a remarkable economic burden on healthcare budget.

One essential aspect that shall be highlighted, however, is that the vast majority of randomized placebocontrolled trials that have been published so far included subjects at the lower end of the distribution of serum $25 \mathrm{OHD}$ concentration, but only a limited number of subjects with real Vit D3 deficiency (Table 1). This leads the way to planning future tailored studies aimed at establishing whether public health actions based on vit D3 supplementation or food fortification will really be effective for reducing the risk of acute or chronic diseases in subjects with Vit D3 deficiency, whose number is exponentially increasing around the world (19). Additional efforts shall also be made for eliminating or lowering the impact of many important confounders of Vit D3 status in future epidemiological investigations (20).

\section{Acknowledgments}

None.

\section{Footnote}

Conflicts of Interest: The authors have no conflicts of interest to declare.

Ethical Statement: The authors are accountable for all aspects of the work in ensuring that questions related to the accuracy or integrity of any part of the work are appropriately investigated and resolved.

\section{References}

1. Lippi G, Cervellin G, Danese E. Indoor Tanning a Gianus Bifrons: Vitamin D and Human Cancer. Adv Clin Chem 2018;83:183-96.

2. Holick MF, Binkley NC, Bischoff-Ferrari HA, et al. Evaluation, treatment, and prevention of vitamin D deficiency: an Endocrine Society clinical practice guideline. J Clin Endocrinol Metab 2011;96:1911-30.

3. Holick MF. Resurrection of vitamin D deficiency and rickets. J Clin Invest 2006;116:2062-72.

4. van Schoor N, Lips P. Global Overview of Vitamin D Status. Endocrinol Metab Clin North Am 2017;46:845-70.

5. Heureux N. Vitamin D Testing-Where Are We and What Is on the Horizon? Adv Clin Chem 2017;78:59-101.

6. Scragg R. Emerging Evidence of Thresholds for Beneficial Effects from Vitamin D Supplementation. Nutrients 2018. doi: 10.3390/nu10050561.

7. Pilz S, März W, Cashman KD, et al. Rationale and Plan for Vitamin D Food Fortification: A Review and Guidance Paper. Front Endocrinol (Lausanne) 2018;9:373.

8. Lai YH, Fang TC. The pleiotropic effect of vitamin D. ISRN Nephrol 2013;2013:898125.

9. Targher G, Pichiri I, Lippi G. Vitamin D, thrombosis, and hemostasis: more than skin deep. Semin Thromb Hemost 2012;38:114-24.

10. Pilz S, Zittermann A, Trummer C, et al. Vitamin D testing and treatment: a narrative review of current evidence. Endocr Connect 2019;8:R27-43.

11. Manson JE, Cook NR, Lee IM, et al. Vitamin D Supplements and Prevention of Cancer and Cardiovascular Disease. N Engl J Med 2019;380:33-44.

12. Pittas AG, Dawson-Hughes B, Sheehan P, et al. Vitamin D Supplementation and Prevention of Type 2 Diabetes. N Engl J Med 2019. [Epub ahead of print].

13. Roth DE, Morris SK, Zlotkin S, et al. Vitamin D Supplementation in Pregnancy and Lactation and Infant Growth. N Engl J Med 2018;379:535-46.

14. Bischoff-Ferrari HA, Willett WC, Orav EJ, et al. A pooled analysis of vitamin $\mathrm{D}$ dose requirements for fracture prevention. N Engl J Med 2012;367:40-9.

15. Aspray TJ, Chadwick T, Francis RM, et al. Randomized controlled trial of vitamin $\mathrm{D}$ supplementation in older people to optimize bone health. Am J Clin Nutr 2019;109:207-17.

16. Aloia JF, Katumuluwa S, Stolberg A. et al. Safety of calcium and vitamin $\mathrm{D}$ supplements, a randomized 
controlled trial. Clin Endocrinol (Oxf) 2018;89:742-9.

17. Letavernier E, Daudon M. Vitamin D, Hypercalciuria and Kidney Stones. Nutrients 2018. doi: 10.3390/nu10030366.

18. Galior K, Grebe S, Singh R. Development of Vitamin D Toxicity from Overcorrection of Vitamin D Deficiency: A Review of Case Reports. Nutrients 2018. doi: 10.3390/ nu10080953.

Cite this article as: Lippi G, Targher G. Are we overrating the extra-skeletal benefits of oral vitamin D supplementation? Ann Transl Med 2019;7(18):499. doi: 10.21037/atm.2019.08.93
19. Palacios C, Gonzalez L. Is vitamin D deficiency a major global public health problem? J Steroid Biochem Mol Biol 2014;144 Pt A:138-45.

20. Lippi G, Mattiuzzi C, Aloe R. The impact of seasonality and other determinants on vitamin $\mathrm{D}$ concentration in childhood and adulthood: still an unresolved issue. Ann Transl Med 2016;4:21. 